日本平滑筋誌 (Jap. J. Smooth Muscle Res.), 12, 25-36, 1976.

\title{
イヌにおける胆囊運動の映像工学的観察
}

\author{
弘前大学医学部 大内外科学教窒 \\ (主任：大内清太教授)
}

工 藤 興 壽

\section{A PHOTO-OPTICAL OBSERVATION OF GALLBLADDER MOTILITY IN DOGS}

\author{
Noritoshi Kuno \\ Department of Surgery Hirosaki University, School of Medicine, Hirosaki \\ (Director: K. Oh-Uti)
}

A photo-optical observation on gallbladder motility was made with the $16 \mathrm{~mm}$ cine-cholangiography. The subjects studied were thirty two mongrel dogs. The gallbladder was exposed by a short upper midline abdominal incision under pentothal anesthesia. Gallbladder bile was aspirated and contrast medium was given into the bladder, through a transhepatic route. The cine-cholangiography was done by an image intensifier at a speed of one frame every 2 to 4 seconds. The cinefilms taken were observed repeatedly by the screen projection at various speeds. The drawings were made by tracing the outline of the image of the gallbladder on each frame and were overlapped. Moreover, a contraction curve was made by the cholecystometry using of film motion analyzer in every case. At the same time bile flow into the duodenum was recorded to study a relationship between the gallbladder contraction and motility of the terminal common bile duct.

The results obtained are as follows:

1. In a resting state any contraction of the gallbladder was not seen during 30 minutes, and a peristalsis-like movements of the neck portion was observed. However, there was not a relationship between the contraction curve of the gallbladder and the bile flow into the duodenum.

2. Immediately after giving Caerulein, the contrast medium injected into the gallbladder was rapidly discharged into the common bile duct by a peristalsis-like movement of the neck. The size of the gallbladder was markedly decreased into three fifths of the initial state three minutes after administration. At the same time contrast medium was continuously discharged into the duodenum.

3. After giving pilocarpine a marked contraction with forceful movement of the neck and body was observed, and the size of the gallbladder was decreased into three quarters of the initial state. Bile discharge into the duodenum was markedly increased with an active open- and closing movement of the terminal common bile duct. 
は じ め に

肝内胆汁が，いかにして十二指腸内に排出され るかについて, これ束で諸分野で多数の研究がな され，その主要因子として肝分泌压，胆囊機能， 胆道末端部運動や十二指腸蠕動などがあげられて いる、しかし，それぞれの機能の詳細やそれらの 相互関係については諸家の意見がなお一致せず未 だ不明の点がすくなくない。

われわれの教室では, これまで胆道運動, 特に 胆管末端部オッジ筋機能と十二指腸筋蠕動との関 係を電気生理学的, X線学的に観察してきた。そ の結果, 胆管末端部オッジ筋は十二指腸壁筋より 機能的に独立した括約作用を有し，これが胆汁の 十二指腸内排出を規制していることを明らかにし

\section{実 験}

\section{I. 実験材料および実験方法}

1）実験動物には体重 5～11 kg の雑種成犬 32 頭を用いた。実験当日朝より絶食した犬を pentothal 静脈麻酔（初回 $20 \mathrm{mg} / \mathrm{kg}$ ，覚醒時 $5 \sim 8 \mathrm{mg}$ / kg の割で追加）のもとに, 柿崎 $\left.{ }^{9}\right)$ が家鬼に使用 した塩化ビニールの固定台を犬用に大きくした固 定台にのせ，手術侵襲による影響をすくなくする ため上腹部に $10 〜 12 \mathrm{~cm}$ 程度のなるべく小さい正 中切開を加え腹腔に到達した。肝上面を通して肝 床より胆囊内に外針 18 ゲージのベニューラ静脈 留置針を刺入し, 胆囊胆汁を $10 \mathrm{~m} l$ 前後吸引した 後, ほぼ同量の Diatrizoate (76\% Urografin) 又 は, Iothalamate 80 (Angioconray)を注入して, チューブを抜去したらえで閉腹した。なお，胆囊 内圧測定の場合にはチューブをそのまま腹壁に固 定し, 随時 electronic manometer と連結して内 圧測定をも同時に行なった。

2）同じ実験動物を使い, 前述の方法のもと で, cholecystokinin 様 polypeptide の caerulein $(0.1 \mu \mathrm{g} / \mathrm{kg})$, 副交感神経末梢刺激剤の pilocarpine $(0.3 \mathrm{mg} / \mathrm{kg})$ 等の薬刘を経静脈的に投与乙胆囊運 動の賦活を試みた。

\section{II. 使用装置および撮影条件}

撮影装置は Philips 社製 9 インチ Image Intensifier を用い, カメラは BOLEX H-16, レンズ は焦点距離 $35 \mathrm{~mm}, \mathrm{~F} 1.5$ を使用した。撮影に際
た 1〜9).

しかし, 胆汁排出には, 胆囊の役割も無視でき ず，これを除外して胆汁排出機転を論ずることは 全くの片手落ちといらほかはない。

そこで著者は，胆囊機能およびそれと胆管末端 部運動との関係を明らかにするため, イヌを用い 胆囊内に造影剤を穿刺注入してなるべく生理学的 環境を維持温存しつつ, 胆道X線映画の撮影を行 ない, 得られたフィルムに映像分析を加えた。そ の後, 同様の環境のもとに, 胆囊収縮賦活剤を投 与しての観察を行なった。 その結果, 胆囊収縮お よび胆管末端部運動との相互関係について若干の 知見を得たのでここに報告する.

\section{方 法}

しては Nac 社製のシネオートタイマー BM2 を用 い,これを自動的に調節した。フィルムはサク ラ，タイプ 6162 を使用した。

体位は固定台にのせたまま背臥位または $45^{\circ}$ 背 腹第 2 斜位とし, 撮影条件は管電圧 $50 \mathrm{kVp}$ 前後, 管電流 $2 \mathrm{~mA}$ 前後, 撮影速度は 2 秒 1 コマまたは 4 秒 1 コマ, 時には 1 秒 12〜16コマとした。

また, 胆囊内圧測定にあたっては, 胆囊内挿入 チューブを, electronic manometer MP24-T（日 本光電) に接続し，これを Multipurpose polygraph RM 150 (日本光電) に連結し, ペン書きに よりこれを測定記録した.

\section{III. 分析方法}

撮影したフィルムについて, Kodak 社製 ANALYST 映写機を用い, 最初スクリーン映写法に よって連続的観察を行ない, ついで stop motion 方式によって間隔的観察を行なった。すなわち $1 / 6$ 秒ないし 2 秒ごとにスクリーン上に投影され た胆囊輪郭をらすい半透明紙にトレースし，これ らをかさねあわせ胆囊輪郭の動きを解析した。重 㸚合せによる運動分析に際し比較的動きの少ない 胆囊底部及び肝床附着部を基線としてえらんだ， また最初のコマの胆囊輪郭を原形としてとり, 次 々これに重ね合せ，原形より収縮した部位を黒く ぬりつぶし, 胆囊の収縮部位およびその推移につ いて検討した。 
さらにアニメーション方式, つまり 2 秒 1 コマ で撮影したフィルムの1コマをトレースし，それ を4 コマに延長して，いわゆるスローモーション 観察を行ない，瞬間的な動きを詳細かつ具体的に 検討した.

また，20 秒ごとのコマをとりだしてそれぞれの
胆囊面積をプラニメーターで測定し，撮影開始時 の面積を 100 としてその後の計測值のこれに対す る比率をグラフにカーブとして描いてみた。すな わち, 胆翼面積推移曲線としてこれを観察し, 胆 管末端部より十二指腸への造影哃排出の状況をも このグラフ上に同時記録し対比観察した。
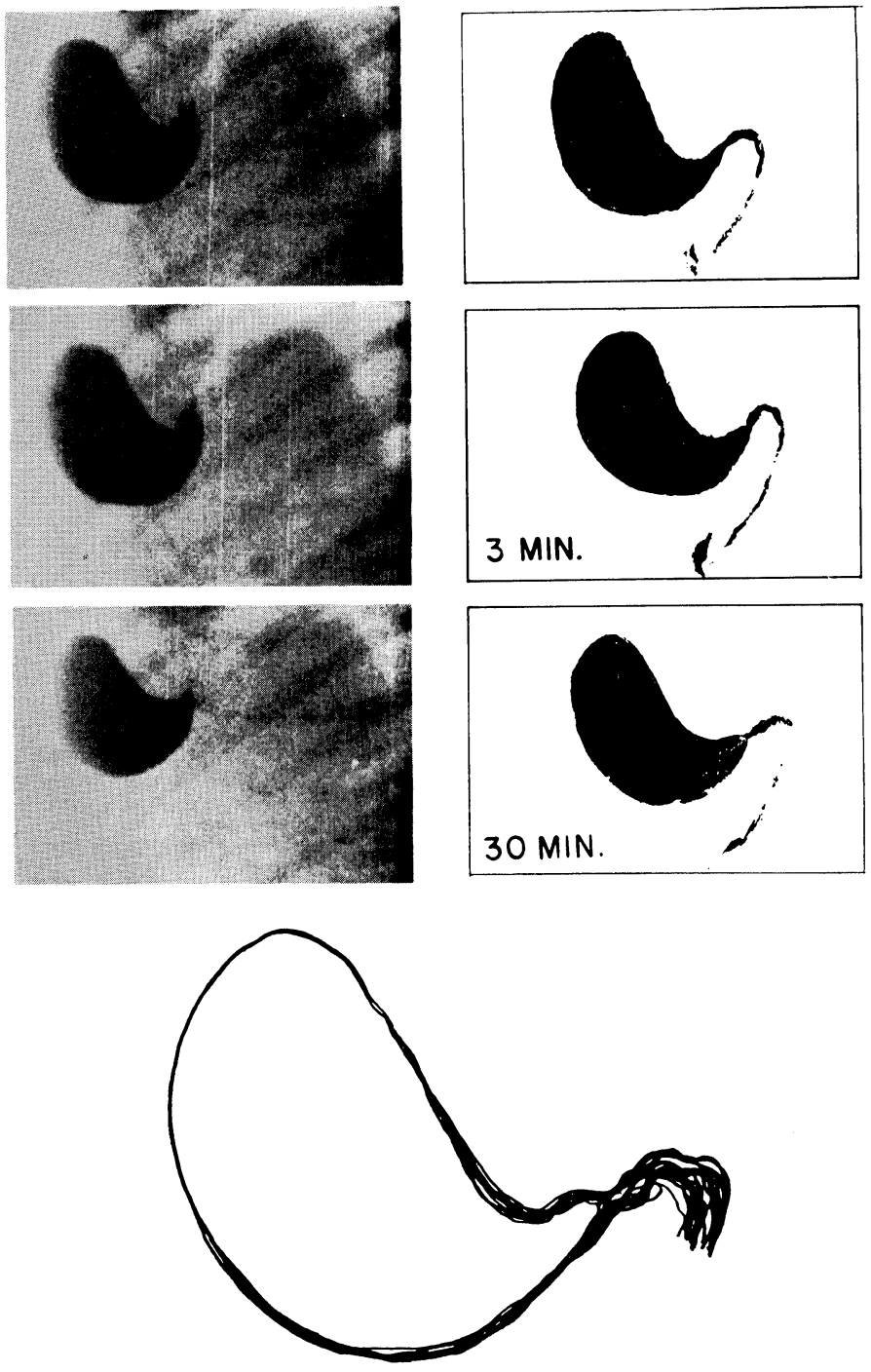

図 1. 妄静無作為時胆囊映像の変化

胆轘はなすび状を呈し，著明な縮小はみられない(上図)。コマごとの重ねあわせを行なうと， 頸部から体部前半にかけて波動様変化ないしは蠕動様運動をうかがうことができる(下図)。 


\section{I. 安静無作為時}

1) 連続的観察 (図 1)

2 秒 1 コマで低速撮影したフィルムを，1秒 16 ないし 24 コマの正常映写速度にて観察すると, 1 時間 30 分〜 2 時間にわたる連続的映像変化が 3〜 4 分に短縮されることになる. そこでそれら の観察結果についてのべると, 胆囊は背臥位で円 形, $45^{\circ}$ 背腹第 2 斜位ではなすび状を呈し, 呼吸 運動による軽度の上下移動はあるが，このような フィルムの連続的映写の肉眼的観察ではその大い さには変化としてみられるにはいたらなかった。 ただ造影剤濃度は, 30 分経過してやや減少する程 度であった。1 コマごとの重ね合せを行ならと， 頸部にかすかな波動様変化ないしは蠕動様運動が 観察された，造影剤注入圧の高い場合には総胆管 は径 $3 \mathrm{~mm}$ 泀どで線状に造影されるが，その際末 端部より造影剤は十二指腸へ断続的にゆっくり排 出られるのが観察された。
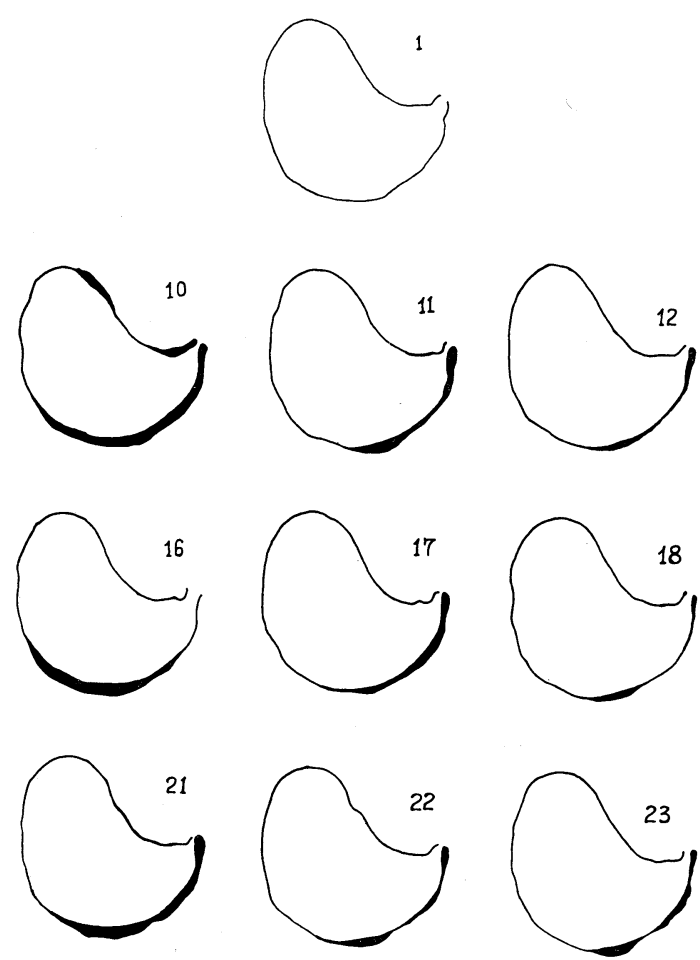

図 2. 無作為時 stop motion 方式による映像変化

( 1 コマ/2秒)

10，16，21 において，頸部より体部にわたる広 範囲な緊張性収縮がみとめられる。
2） Stop motion 万式による観察（図 2)

1 コマごとに胆囊輪郭を半透明紙にトレース し, 最初のコマの胆囊輪郭を原形として, ひきつ ら゙くコマのそれを重㸚合わせて輪郭の位置のズレ によって胆囊運動の変化を検討した.

すなわち, 図 2 のごとく, コマ番号 1 は原形で, それから 10 番目のものでは, 胆囊映像下縁にお いて頸部から体部前半にかけて比較的著明な面積 縮小が認められた（黒くぬりつぶされた部分が 縮小した部分に相当する）ひきつづく 11 ではこ れがやや回復し，12にいたって医涪形に復し た. 2 秒 1 コマの撮影であるため, この経過は汪 ぼ 4 秒となるわけである。この面積縮小は打そら く胆囊の緊張性収縮に由来するものと考兄られ, その変化は頸部より体部前半にかけて著しいよう である.やがてコマ番号 16 に执いて同様の著明 な面積縮小がみられ，17,18に扣いてほ医原形に 回復した。ひきつづきコマ番号 $21,22,23$ にいた ってふたたび同様の変化が観察された。

結局 5〜6 コマつ屯り 10〜12 秒の周期で頸部よ り体部にか㺭ての緊張性収縮がみられ，これがそ れぞれ 4 秒ほどの時間的経過によってほぼ原形に 復していることが観察された。

なお，イスの呼吸数は 1 分間に 20 回前後なの で,この収縮周期とは一致しない。

この収縮期に一致して造影剤が総胆管に排出さ れるか否かについては撮影機器の解像力やフィル ムの粒子面など, 撮影条件の関係でこれを明らか にすることは困難であった。けれどもスクリーン

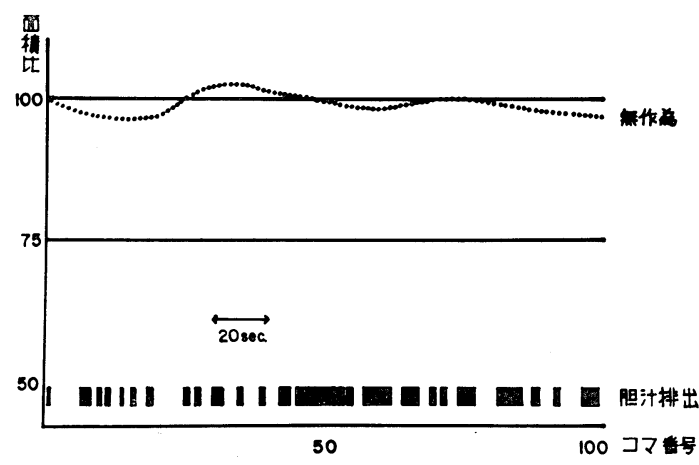

図 3. 胆囊面積推移曲線と末端部胆汁排出 (無作為時) 胆囊面積推移曲線と末端部胆汁排出との間には とくに一定の関係はない 
映写法によって全経過を連続的に微察すると, 前 述のごとく総胆管はスクリーン上約 $3 \mathrm{~mm}$ の径で 線状に造影された。その際胆管末端部が呼父㭙に ややふくらみ, 時々造影剤が十二指晹内に排出さ れるが，その時期はしばしば吸気時と一致して観 察された。

3) 胆囊面積推移曲線と胆道末端部造影剤流出 との関係 (図 3 )

安静無作為時に打忷る胆囊面積推移曲線につい
て微察すると 100 の基線を中心として軽度の増大 と縮小とを反復し, 著明な映像縮小はほとんど忍 められなかった。この推移曲線と胆管末端部造影 剂排出状沉との関係について対比推察すると, 末 端部よりの造影剂排出と推移曲線の下降, 上昇と の間にはとくに一定の傾向をみいだせなかった。

\section{II. 胆襄運動賦活剤を投与した場合}

A. Caerulein $0.1 \mu \mathrm{g} / \mathrm{kg}$ 投与例

1) 連続的観察
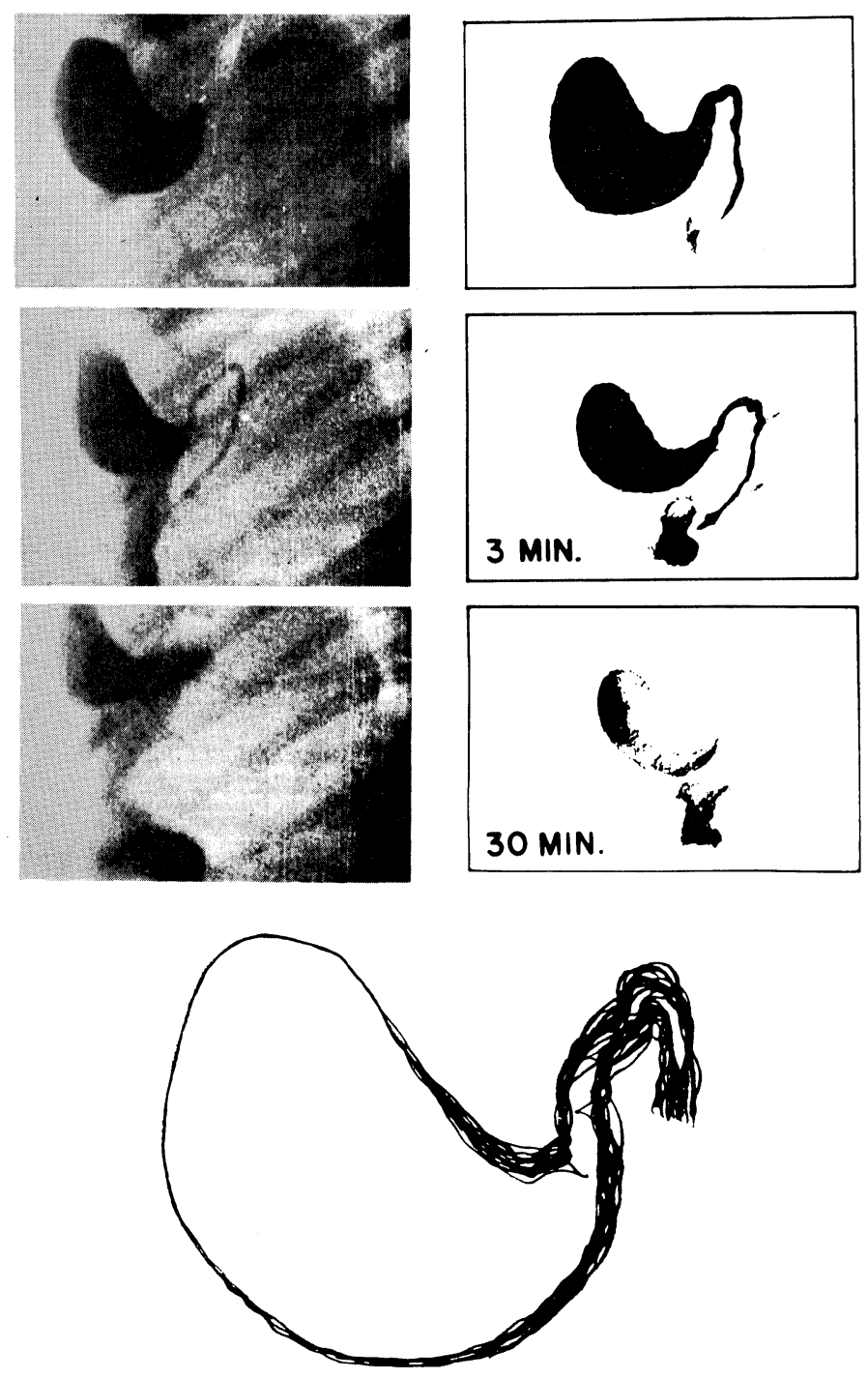

因 4. Caerulein 投与時胆整映像の变化

胆囊頸部の著明な運動変化とともに，造影剂はつぎつぎと総胆管におくりだされ，総胆管はあ たかも蛇ののたうつごどくゆれ動いて造影剂を十二指晹内におくりこむ，胆慗除影の縮小，濃 度の隇少が著明である。 
cholecystokinin 様 polypeptide の caerulein $0.1 \mu \mathrm{g} / \mathrm{kg}$ を静注すると, 静注直後より胆囊頸部 及び体部の著明な蠕動様運動之共に造影剤は次及 と総胆管におくりだされた。 2 秒 1 コマの低速撮 影フィルムを 1 秒 16 コマの正常速度で映写する と, 総胆管はあたかも空のゴムホースに急激に注 水したときのように蛇ののたらつごとく左右には げしくゆれ動き，同時に胆管末端部の活発な開閉 運動がくりかえされ，造影剤はつぎつぎと十二指 腸内へ打くりだされた。

最初の 100 コマ, すなわち注射後約 3 分程で胆 囊映像は著明に縮小し, それ以後はむしろ濃度の 減少が目立ってきた。この縮小の際，全体とし映 像形態には注とんど变形がなく幾何学的相似形の proportion を保ったまま小さくなった(図4).

animation による観察では，体部全般にわたっ ての緊張性収縮とともに，頸部より胆囊管にかけ ての活発な蠕動様運動が更に明確に観察された。 また，造影剤の排出にともない，総胆管は左右に 蛇行するとともに，その太さも刻々と変化し，同 時に末端部の律動的な開閉運動がみられ, 造影剤 はつぎつぎと十二指腸内の排出され，それにとも
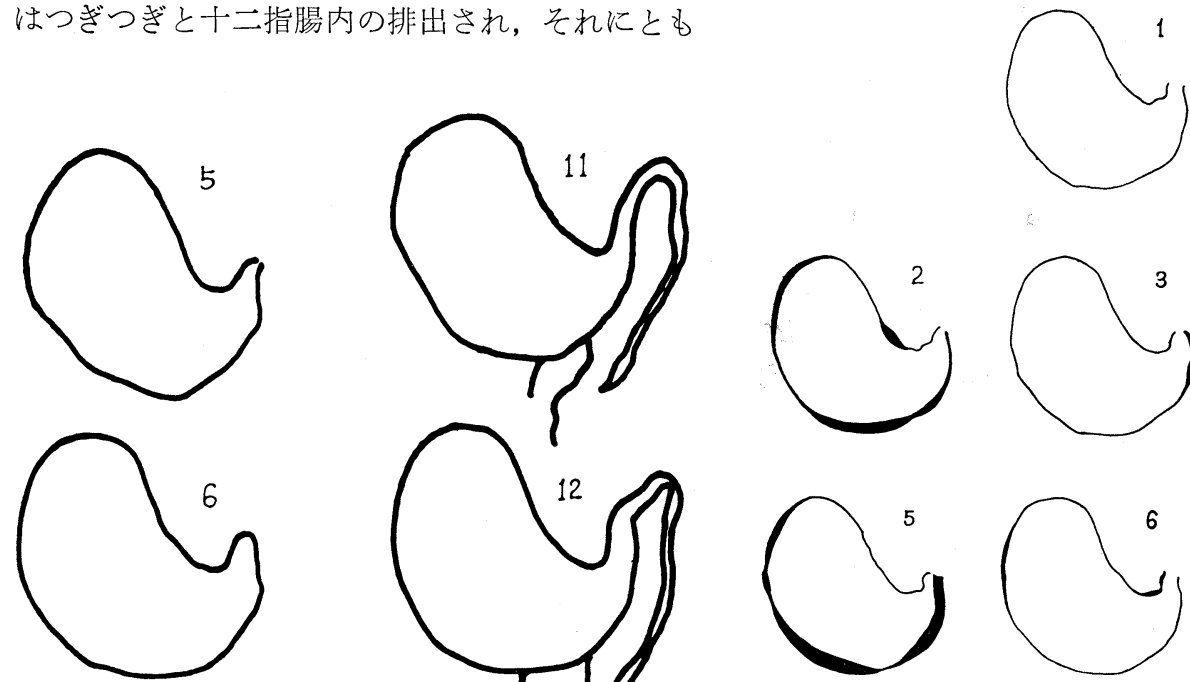

\section{(図 5 ).}

また，なかには映像の縮小と濃度の希薄化とが 同時に起り約 3 分 30 秒で胆囊映像の完全な消失 をみるものもあった。

2) Stop motion 方式による観察（図6)

caerulein 投与直後より, 無作為時に比較し, 頸部から体部, さらに底部にか将活発な収縮運動 が観察された。すなわち, 図6のごとくコマ番号 1 (caerulein 投与直後) が原形で，2のコマにお いては頸部, 体部前半, さらに底部に扣いて面積 縮小があり，3，4 と約 4 秒経過してもとにもど り,さらに 5 において 2 にみられたよりさらに著 明な縮小が出現し，6，7 と一旦回復した。ついで 8 になってふたたび著明な縮小があらわれ，これ は胆囊の汪とんど全域にわたって観察された。結 局, 緊張性収縮は 3 コマごとにあらわれ, 体部か ら底部にか将て広範囲かつ強大な収縮が観察され た。

すなわち，連続的観察およびアニメーションに
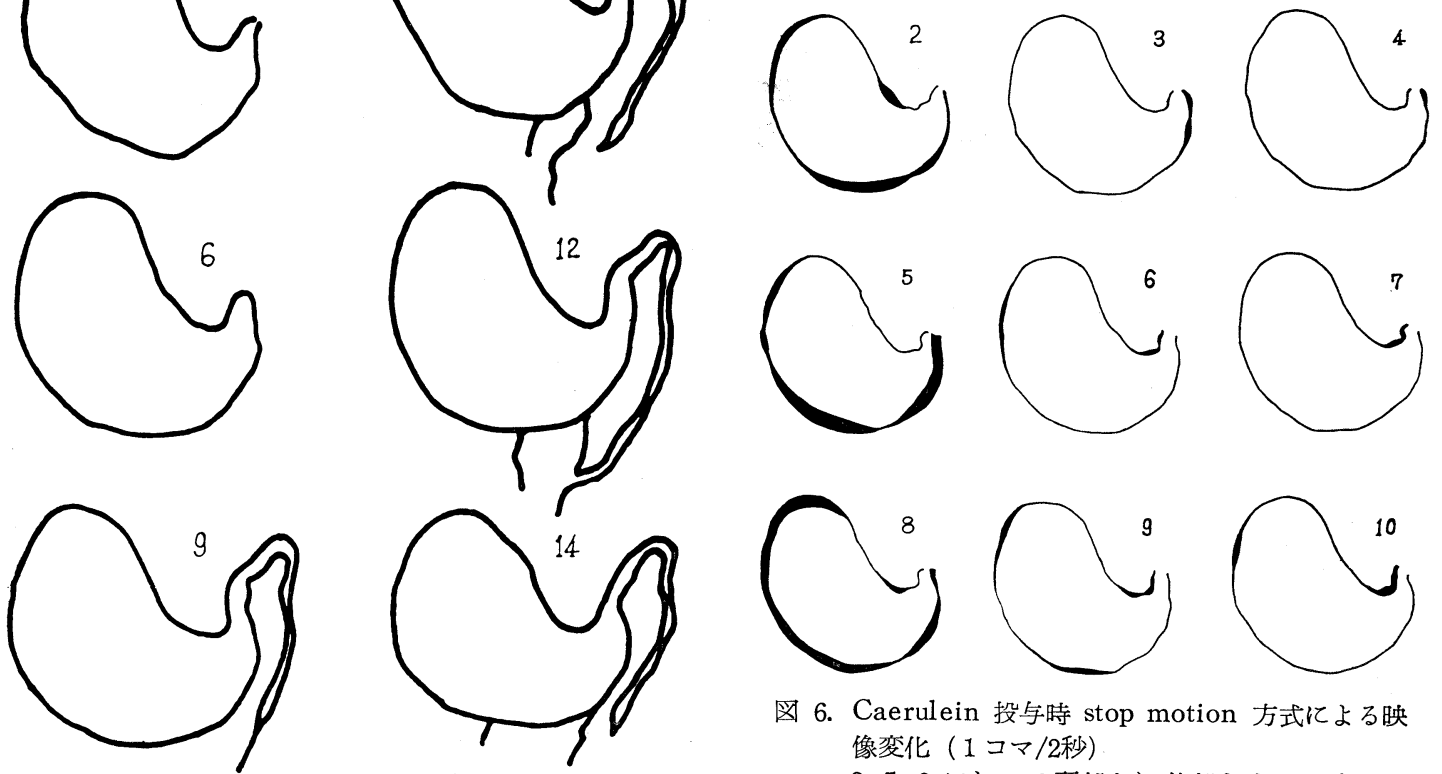

図 6. Caerulein 投与時 stop motion 方式による映 像変化 (1 コマ/2秒)

$2,5,8$ 亿おいて 頸部より体部さらには底部に で及ぶ広範囲な收縮がみられる。

図 5. Caerulein 投与時, アニメーションによる観察 
よる钼察に拈いてみられた頸部より体部にかけて の蠕動様運動は，1コマごとの部細な分析によ り, 向底, 向頸いずれにも進行しない周期約 6 秒 の頸部から体部, 底部にわたる公範囲な緊涱性收 維であることが明らかとなった。そしてこのよう な周期的収縮によって, 後述するごとく胆露は段 階的に縮小してゆくものと考兄られる.

3）胆䠛面積推移曲線と胆道末端部造影郕流出 との関係 (図 7 )

胆霊面積推移曲線についてみると, caerulein 投与後最初の 40 コマ, 寸なわち約 80 秒にわたっ て一様な勾配での下降がみられ，ついで $2 \sim 3$ ケ のら㸚りを描いて推移し, 投与後 3 分程で映像 は約 $3 / 5$ に縮小した。一方末端部造影剤排出との 関係について観察すると, 最初断続的に排出され ていた造影剂は 25 ユマ目，すなわち投与後 50 秒 附近から持続的にみられるよらになり，途中若干

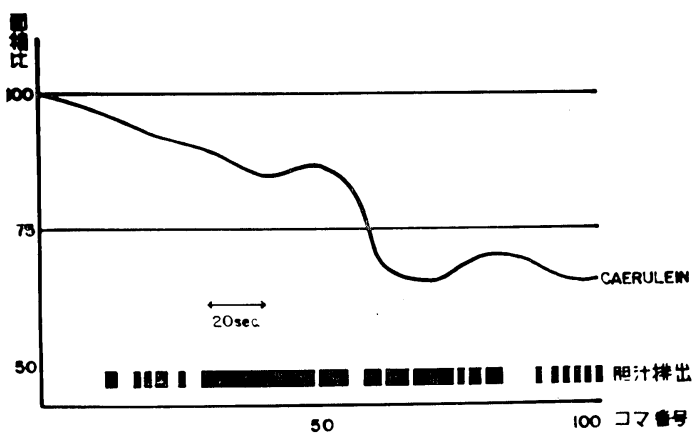

(A)

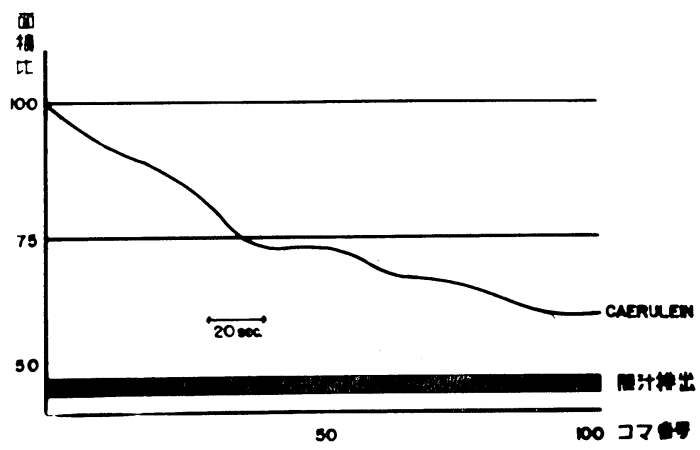

(B)

因 7. 胆壊面積推移曲線と末端部胆汁排出 caerulein 投与後 3 分程で映像は約 $3 / 5$ 亿縆小 する。最初断続的に末端部より排出されていた 造影剂は2 25 コマ目附近汃ら持続的にみられる ようになる $(\mathrm{A})$ 。また，最初から持続们に末 端吅より造影版つ排出をみるものもあった $(\mathrm{B})$.
の中断もみられるが，その效果は約 2 分間にわた って継続した。 その後再び断続的な排出状況に復 雀するよらになっだ（図7-A）

また曙合によっては，全経過にわたりほぼ一様 の公唒で下降する推移曲線を示し，同時に持続的 に末端部造影郕排出をみるものもあった。（図7一 B)

4) 胆䔶内儿:曲線（図 8 ）

32 例のらち，4 例に胆露内压を測定記録した が，その 1 例を亦した。無作為時， $130 \mathrm{mmH}_{2} \mathrm{O}$ 前後で, 調律的変動していたものが, caerulein

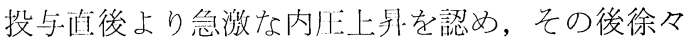
に減少し約 1 分 30 秒で敖止眝压に復州した。

\section{B. Pilocarpine 投与例}

\section{1) 速続的钼察}

副交感神経末梢刺激剂の pilocarpine $0.3 \mathrm{mg} / \mathrm{kg}$ を静注すると, 注射後 1 分以内に頸部から体部に かけての蠕動様運動が著明に括こり，胆垔咉像は 縮小し, 濃度の減少がみられた。この運動変化は caerulein 投与の際みられた変化よりる，さらに 強大から著明なるのがあった（図 9 ）。

2) Stop motion J式による微察（図 10）

pilocarpine 投与例では， caerulein 投与例と同 様収維が大であるが胆鿊の変形が著しい。すなお ち図10のごとく，コマ番号 7 で体部前半に面積 縮小が発現し，8でこれが頸部なでおよび 9 で䋹 小效果が最大となる。コマ番号 10 で収維が底部 にも発現し, 胆曧垃径が短縮するため全体として 胆囊は円形となり，4コマつまり約 8 秒の後コマ 番号 14 で緮小効快がもっとも著明となった。そ の後コマ番罗 19 より，钚径が扗び增大しはじめ,

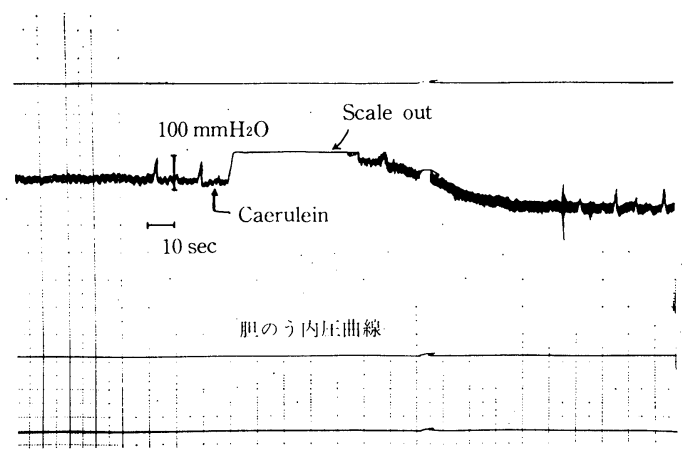

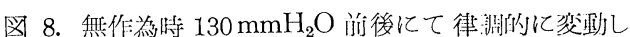
ていたものが， caerulein 投与直後より念激な 内圧上是古溻める。 
22, 23 と医涪同様の变化が続いてから回復にむか い, コマ番号 28 で注湆原形にもどった。

以上, 頸部より体部さらに底部にお゙よぶ広範囲 かつ強大な収縮が約 54 秒間にわたり観察された。 すなわち, 平滑筋に痤攣を扣こし, 胆囊を収縮さ せるといわれている pilocarpine 投与により, 無 作為時および caerulein 投与時よりもさらに強大 な胆囊収縮が観察された。

3）胆囊面積推移曲線之胆道末端部造影剤流出 との関係（図 11）

面積推移曲線についてみると, 最初の 30 コマ,
すなわち約 60 秒間は一様の勾配で下降しほぼ原 形の $3 / 4$ 大に縮小し, その後縮小は汪とんどみら れなくなる。一方造影剤排出との関係について は， caerulein 投与時に比較し造影剤排出ならび に中断時間の延長が認められた。

すなわち, pilocarpine 投与により胆道末端部 より十二指腸への造影剂排出, 中断効果が著明に 起り，末端部の律動的な運動六進をらかがうこと ができた．前述した強大な胆囊収縮を起すことを 考え合せてみると pilocarpine は胆道系全般の運 動を促進するものと考えられた。
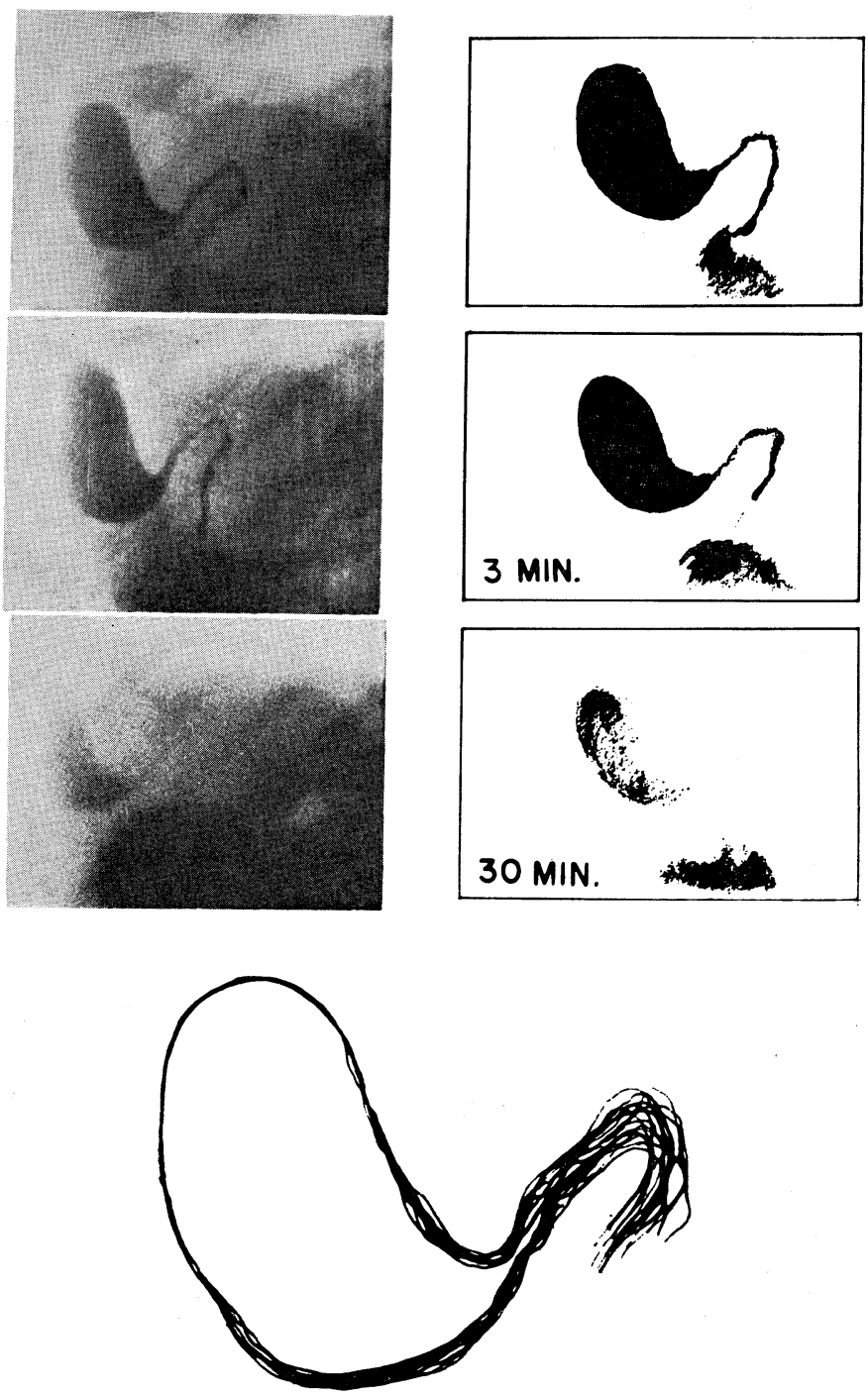

図 9. Pilocarpine 投与時胆霊映像の変化

胆囊頸部より体部にかけての著しい運動変化とともに，造影剤は総胆管におくりだされる。 


\section{総 括 と考案}

胆汁排出機転に怙いて胆囊運動の果す役割は極 めて重要であるにもかかわらず, その詳細に関し てはこれまで不明の点がすくなくなかった。した がってその本態にせまろらとするアプローチの手 段も多種多様にわたり，たと光ば，X線による観 察 ${ }^{10 ~ 14)}$, 直接開腹観察法 ${ }^{15,16)}$, 生体についての胆 道内压曲線描写法 ${ }^{15,17 ~ 26)}$, 超生体実験によるも $の^{26 \sim 30)}$ ，生体活動電位描写法 ${ }^{12,31 ~ 34)}$ など諸観察 法が行なわれてきた。けれども，これら観察法の 大部分は生理的状態からかなりかけはなれた環境 で行なわれており，かならずしもその本態を正し くとらえているとは限らないよらに思われる。

そこで著者は, イヌを用いその生理学的環境を なるべく温存した状態で胆囊機能，とくにその収 縮運動による胆汁の総胆管ならびに十二指腸への 排出効果について映像工学的に観察を試及た。す なわち, 肝床より胆囊への穿刺を行ない胆汁と造 影剤を置換してX線映画撮影を行ない, 自然状態
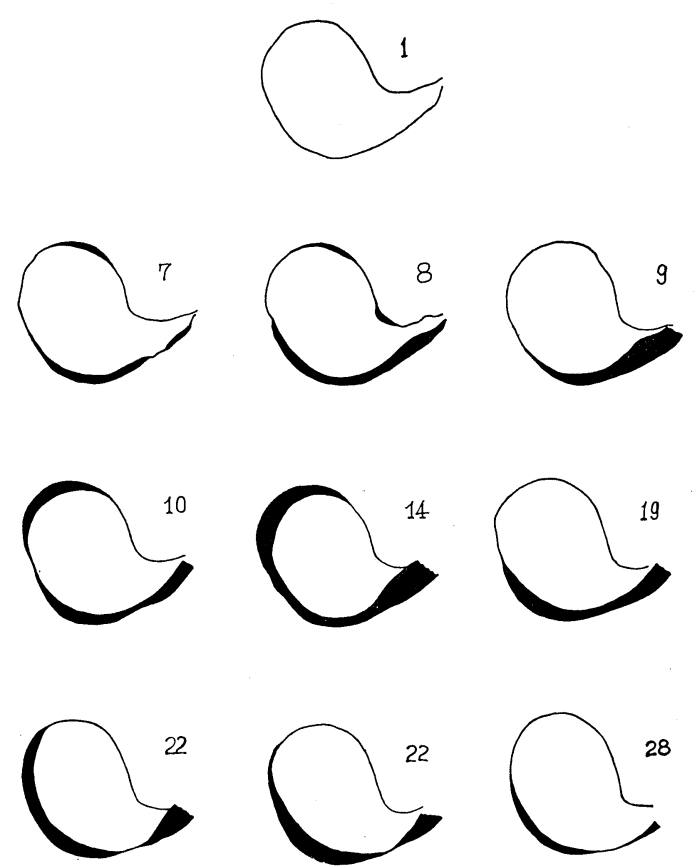

図 10. Pilocarpine 投与時 stop motion 方式によ る映像変化

7 で体部から頸部にかけての収縮がおこり， 10 で収縮が底部にまでおよび，14で胆霬は円 状となりその後長径が増大して $28 て ゙ 1$ と同形 になる。
での胆囊運動とそれにともなら造影剤の排出状沉 について映像分析を行なった。

X線映画撮影にあたっては, 緩慢な胆囊運動を 長時間にわたって観察する関係上，斉藤 ${ }^{11)}$ が行な った方法すなわち， 2 分間連続撮影法，1 分間の 間隔を扎いての連続撮影, 2 秒 1 コマ 20 分間の低 速度連続撮影などに改良を加え, 1 秒 12〜16 コマ の連続撮影， 2 秒または 4 秒に 1 コマの 1 時間 30 分ないし 2 時間にわたる低速 $\mathrm{X}$ 線映画の撮影を行 なった。

この低速 X線映画撮影により, 従来不充分だっ た長時間にわたる経時的胆囊形態の連続的観察が 可能となった。すなわち, 1〜2 時間の胆囊映像の 変化が，正常速度（16〜24コマ/秒）撮影により, $3 \sim 4$ 分間に圧縮されきわめて明膫に観察するこ とができた、さらに, 胆囊輪郭を一枚ごとにトレ 一スし，それらを重㸚合せたり，プラニメーター でその面積の推移を計測することにより, 運動形 態の詳細を綿密に分析することができた。 また 4 コマ程度の適度なコマのばしによりアニメーショ ン作成を行ない,より具体的に運動の詳細を観察 することができた。

さて胆囊運動に関する報告としては, Doyon ${ }^{17)}$ がイヌの胆囊に balloon tube を挿入しその内圧 変化を測定したのにはじまる．彼によると，2〜5 分間隔で 1 分間 3〜4 回の緩徐かつ不規則な胆囊 の内圧変化を観察することができたという．その 後, Bainbridge \& Dale ${ }^{19)}$, Okada ${ }^{22)}$ がこれに よく類似した結果を報告している。また同じ頃,

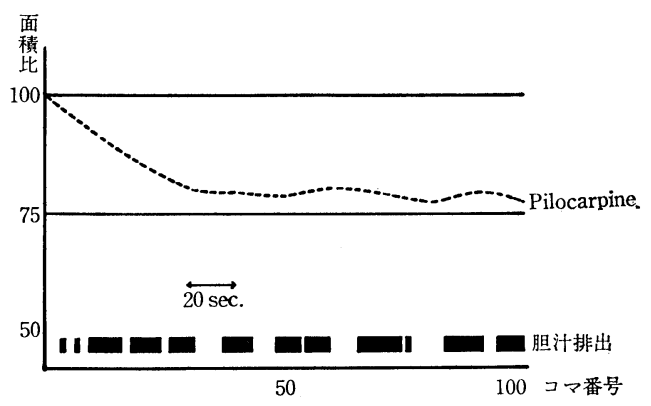

四 11. 胆襄面積推移曲線と末端部胆汁排出 pilocarpine を投与すると，3 分程で約 $3 / 4$ に縮小し未端部より造影剤排出ならびに中断 時間の延長が認められる。 
Graham \& Cole ${ }^{10)}$ が, はじめてX 線による生体 胆囊造影に成功し胆囊収縮を確認して胆道疾患診 断に新しい分野を開拓した。

その後諸家による研究が進み, 胆囊運動には contraction と peristalsis の 2 形式が存在すると され，特に頸部の運動变化が注目されるようにな ってきた。わが国に扮いても，三宅 ${ }^{34)}$, 津下 ${ }^{35)} ら$ は, 解剖学的研究から筋層は全体として菲薄であ るが, 頸部において著明に発達し,さらに神経網 も頸部に濃密に分布して括り, これらの形態学的 特徵とその部の運動機能との関連性について推論 している.

斉藤 ${ }^{11)}$ は生体 $\mathrm{X}$ 線撮影法により, 胆囊胆汁排 出の第一主力として, 底部掞よび体部に拈ける一 様な持続的能動的収縮, 第二主力として漏斗部か ら頸部にかけて周期的 4 30 秒の能動的な拡大拉 よび収縮の運動を観察しこれを胆囊の蠕動である としている，筋電図学的にも谷奥 ${ }^{12)} は$, 頸部は 底部に比較し放電スパイクの数, および振巾が大 であるとし，石川 ${ }^{14)}$ も頸部の方にスパイク，振 巾の優位なことを報告している。

さらに，田北，松永 ${ }^{30)}$, 三宅 ${ }^{27)}$, 松永 ${ }^{15)}$, 田北・ 西島 ${ }^{36)}$ らは，超生あるいはネコの腹空法による 生体観察を行ない, 胆囊運動形式を, 基本的律調 性収縮運動と, 比較的緩慢なる律調性緊張性伸縮 現象，およびきわめて緩慢なる持続的緊張性収縮 の 3 つに分類している. 基本的律調性収縮運動は 周期約 20 秒で, 小型の場合, 頸部輪状筋収縮の みをみることが多く, 律動が大となると, 全平滑 筋群が共働的に運動に参与し完全なる向底部進行 性蠕動波を形成するとのへ，これを胆汁の胆囊内 流入の為の運動とみなしている.

著者も，前述したような観察手段により，イヌ 胆囊の安静無作為時連続的観察において, 緩慢な る緊張性収縮のほかに頸部ないし体部に蠕動運動 に類似した所見を認めることができた。そこで撮 影フィルムの stop motion 方式による検討を行な たところ, 10〜12 秒の周期で頸部から体部にかけ ての広範团な緊張性収縮が認められた。なおイヌ の呼吸数は 1 分間に 20 回前後なので,この収縮 周期とは一致しない。

さて, 胆囊運動と総胆管末端部括約作用との関 係について, Meltzer ${ }^{37)}$ は十二指腸内にゾンデを 插入し, 硫酸マグネシウムを注入した際に胆囊収
縮とオッジ筋開大とが同時に起るとの contrary innervation 説を提唱した。 その後, McMaster \& $\mathrm{Elman}^{20)}$ が 永久性胆汁瘦犬を使い内圧を測定し てこれを支持した。 三宅 ${ }^{34)}$ ，津下 ${ }^{35}$ ) らは神経組織 学的検索から, 神経短絡はないが壁内神経におい て胆囊一肝内胆管一肝外胆管一十二指腸壁一いわ ゆるオッジ筋との間にそれぞれ複雑な神経の交通 が存在し胆道系全般の運動に就ける協調作用が行 なわれ得るとしている。

一方, Burget ${ }^{18)}$ は, 内圧測定により胆囊収縮は 補助的なものであり, 相反神経支配は根拠がない

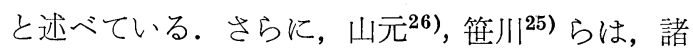
種薬物を投与して内圧を測定し, morphine 以外 は, 胆囊, 末端部とも同時緊張又は緊張下降をき たすとしており，相反神経支配説に反対の意見を もつものが多い.

著者の観察によっても, 安静無作為時, 胆囊面 積は基線を中心にゆるやかな増減のカーブを描く が，末端部造影剤排出との間には，特に一定の関 係をみいだせなかった。

ついで, 著者は, 前述した実験方法で胆囊運動 賦活の目的で, caerulein, pilocarpineを投与し, その際の胆囊運動および末端部よりの造影剤排出 状態を観察した。

caerulein は, Australian frog caerulea の皮か らメタノールで抽出された cholecystokinin 類似 の polypeptide で, 胆囊を収縮させ同時に胆管末 端部を弛緩開大させる作用を有し，その効力は cholecystokinin よりさらに強大なものとされてい $ろ^{38)}$.

この caerulein $0.1 \mu \mathrm{g} / \mathrm{kg}$ を静注すると, 投与 直後より無作為時に比し頸部から体部にかけての 動きも活発になり, 内圧も急上升し, 大方は約 3 分で投与前の約 $3 / 5$ 大となった. stop motion 方 式による胆囊輪郭の重ね合せ観察では, 周期約 6 秒で, 頸部より体部さらには底部におよぶ広範囲 な緊張性収縮が認められた。胆囊面積推移曲線と 末線部造影剤排出との関係をみると, 面積推移曲 線は，2，3 ケのう称りを描いて下降し caerulein 投与後 25 秒附近から, 末端部よりの造影剤排出 は持続的になり, 途中若干の中断はあるがその状 態は約 2 分間継続する. 又, あるものでは面積推 移曲線は。一様の勾配で下降し末端部よりの造影 剤排出が最初から持続的に観察されるるのもあっ 
た。

以上, caerulein の作用すなわち, cholecystokinin より強大な効力を有し, 胆囊を収縮させ，才 ッジ筋を弛緩させるとの報告に一致している。

pilocarpine は副交感神経末梢刺激剤で平滑筋

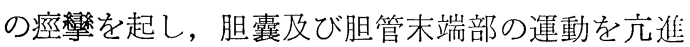
させるとされている。

pilocarpine $0.3 \mathrm{mg} / \mathrm{kg}$ を静注すると約 1 分で頸 部, 体部に活発な变化を伴なった縮小運動が起 り, 約 3 分でその大いさは約 $3 / 4$ となった. stop motion 方式の観察では, 特異な収縮運動が観察 された。すなわち頸部より体部にかけ広範囲な収 縮が起り，それを増強して胆囊は球状となり，湫

\section{む}

雑種成犬 32 頭を用い，生理的環境をなるべく 温存した状態.すななわち開腹して肝を通して胆 囊内にベニューラ静脈留置針を挿入し，胆汁を Diatrizoate または Iothalamate 80 に置換して, 1 秒 12〜16 コマ, 2 秒または 4 秒 1 コマなどの各 種スピードによるX線映画撮影を行なった。撮影 フィルムの映像分析にあたっては，スクリーン映 写法による連続的観察と stop motion 方式によ る間隔的観察を行なった。また, 胆囊運動と総胆 管末端部運動との関係をみる為, 胆囊面積推移曲 線と,末端部胆汁流出の有無とを同時に記録し検 討を加えた。得られた結果を要約すると，

1）安静無作為時連続的観察では, 胆囊映像の 著明な縮小はみられず，頸部および体部に蠕動椂 運動が認められた. stop motion 方式による観察 では, 周期 10〜12 秒で, 頸部から 体部にわたる 緊張性収縮がみられた。しかし, 胆囊収縮と総胆 管末端部よりの造影剤排出との間には一定の傾向 はみいだせなかった。

2）前述した実験方法のもとに， caerulein，pilocarpine を投与し観察すると，

a. Caerulein $0.1 \mu \mathrm{g} / \mathrm{kg}$ 投与例

2 秒 1 コマ撮影したフィルムを 1 秒 16 コマの

\section{文}

1) Ishioka, T.: Electromygoraphic study of the choledochoduodenal junction and duodenal wall muscle. Tohoku J. exp. Med., 70, 73-84, 1959.
法 54 秒で原形にもどる. 面積推移曲線で約 60 秒 間は一様の下降線をたどるが，その時末端部より の造影剤排出および中断の時間が延長した。

すなわち，著者の観察は pilocarpine 投与によ り, 胆㖶, 胆道末端部ともに緊張し, 特に胆囊収 縮が大となり末端部抵抗に打ちかって十二指腸内 胆汁排出が起るとの説 25,26$)$ に一致した。

以上, 胆䔩運動を $\mathrm{X}$ 線映画撮影にて, 映像工学 的にかなり具体的に観察することができた。今 後, 肝胆汁の胆囊内流入機転について検索をすす めるとともに, 呼吸による腹圧の変動との関係, 十二指腸運動との関係について研究をすすめ, 胆 囊運動のより詳細な解明につとめたい。

\section{す び}

正常速度で映写すると, 投与直後より, 胆霊頸部 より底部にわたる蠕動様運動とともに, 総胆管は 左右にはげしくゆれ動き, 活発な造影剂排出が起 り, 投与後 3 分程で胆囊映像は約 $3 / 5$ に縮小し た. stop motion 万式による観察では, 周期約 6 秒で頸部から底部にわたる緊張性収縮が認められ た。また，胆囊収縮盛んな時には概ね総胆管末端 部より持続的に造影剤が排出された.

b. Pilocarpine $0.3 \mathrm{mg} / \mathrm{kg}$ 投与例

投与後 1 分程で頸部，体部に活発な变化を伴な った胆囊映像の縮小運動が起り，3 分程でその大 いさは約 3/4 となった. stop motion 万式による 観察では, 頸部より体部にかけての広範囲な緊張 性収縮が起りそれが増大して胆霬映像は円状にな り，約 54 秒で原形にもどった。 また，胆囊収縮 にともない，総胆管末端部よりの退影剤排出およ び中断時間の延長がみられだ。

稿を終るにのぞみ，御指䓕を御校閣を賜わった弘前 大学医学部第 2 外科学教空大内清太教授に深甚なる謝 意を撁げるとともに，終始直接行御指䆃，御助言を下 さった小野慶一助教授，また研究に御拹力をいただい た医局諸先生，中央放射線診療部坂本哲夫技官に深く 感謝の意を表します。

\section{献}

2）葛西銀朗： 総胆管末端部の神経支配に関する電 気生理学的研究. 弘前医学, 11，293-299，1960。

3）津島恵輔： 犬に抢泹朋排出機能の $X$ 線映画 による研究. 日外会誌，65，1189-1198，1964. 
4）椳哲夫：十二指腸壁筋および Oddi 氏筋部の活 動電流について. 総合医学, 17, 132-136, 1960.

5）梖哲夫：胆汗排出におけるオッジ筋の機能的独 立性について. 東北医誌，63，36-48，1961.

6) 小野慶一ら：胆汁流出とオッジ筋十二指腸の電 気的活動. 日本医事新報，2198，15-25，1966.

7) Ono, K. et al.: Bile flow mechanism in man. Arch. Surg. 96, 869-874, 1968.

8) 土田博：胆汁排出機転に関する電気生理学的な らびにレ線学的研究. 日平滑筋誌，4，103-114, 1968.

9）柿崎潤三： 内圧・筋電図およびX 線映画 3 現象 同時記録法による 家鬼胆管末端部運動の 観察. 日平滑筋誌， 6，40-49，1973.

10) Graham, E.A. \& Cole, W.H.: Roentgenologic examination of the gallbaldder. J.A.M.A., 82, 613-614, 1924.

11）斎藤直衛：生體「レ」線活動寫真 $ニ コ ル$ 胆囊内 容排除運動ノ研究. 日外会誌，40,1161-1244, 1939.

12）谷奥啓一郎：胆霊, 胆道系運動のレントゲンシ ネマトグラフィーおよび筇電図学的研究. 三重 医学, 4, 1838-1849, 1960.

13) Levine, S.: Contraction of gallbladder seen in man. Arch. Int. Med., 40, 420433, 1927.

14）山川邦夫, 岩田竜三郎: Gastrointestinal hormon に関する研究特に cholecystokinin の使 用経験. 消化器病の臨床, 4, 538-546, 1962.

15）松永英剛：胆裳運動の分析的研究. 福岡医誌, 44, 31-41, 1953.

16) 松尾厳： 胆囊疾患に就て。 日内会誌，12，215259, 1925.

17) Doyon, M.M.: A letude de la contractilite des voies biliares. Archieves de physiologie normale et pathologuque, 5, 678-685, 1893.

18) Burget, G.E.: The regulation of the flow of bile. Amer. J. Physiol., 81, 422-430, 1927.

19) Bainbridge, F.A. \& Dale, H.H.: The contractile mechanism of the gallbladder and its extrinsic nervous system. J. Physiol. 33, 138-155, 1905.

20) McMaster, P.D. \& Elman, R.: On the expulsion of bile by the gallbladder and recipirocal relationship with sphincter activity. J. Ext. Med., 44, 173-198, 1926.

21) Kozoll, D.D. \& Necheles, H.: A study of the mechanics of bile flow. I. Responses to physiological intravenous solutions. S.G.O., 74, 27-34, 1967.

22) Okada, S.: On the contractile movement of the gallbladder. J. Physiol. 50, 42-46, 1915.

23）堀内弘：総胆管内圧並びに十二指腸内胆汁流出 と胆蕒. 日外会誌，65，31-46, 1964.

24）林篤彦：旰汁排出機転に関する電気生理学的研 究. 福岡医誌，54，307-329, 1963.

25）笹川庄三：諸種自律神経毒の胆汁流出に及沽す 影響に関する実験的研究. 日内会誌，48，10901096, 1959.

26) 山元七次：䀒外胆道の薬理学的研究. 医学研究, 22, 564-578, 1952.

27）三宅博：胆道十二指腸系の運動機能について. 日外会誌, 53, 482-484, 1952.

28) 田北周平, 矢津充：胆汁の流出は如何にして起 るか. 臨床卜研究, 28, 437-441, 1951.

29) 中山沃：胆道系運動の 神経性 および 化学的調 節. 岡山医誌, 81, 1-11, 1969.

30) 田北周平, 松永英剛: 胆囊は如何様に動くか. 最新医学, 6, 1053-1057, 1951.

31) Ludwick, J.R. \& Bass, P.: Contractile and electric activity of the extrahepatic biliary tract and duodenum. S.G.O., 124, 536546, 1967.

32）鈴木尚温：胆囊運動の筋電図学的研究. 三重医 学, 10, 299-313, 1967.

33）石川嚴, 竜礼之助, 小沢哲郎：胆囊の 筋電図学 的研究. 東邦医会誌, 15, 81-88, 1968.

34) 三宅博：胆道の疼痛 (其一総論)。臨床と研究, 26, 496-501, 1949.

35) 津下健哉：旰外胆道の解剖学的研究. 岡山医誌, 64, 517-540, 1952.

36) 田北周平，西島早見：胆汁分泌排泄の生理特に 胆囊及び胆管の運動。医学シンポジウム第 13 輯 胆慗・胆道疾患, 79 頁, 診断と治療社, 東京, 1957.

37) Meltzer, S.J.: The distrubance of the law of contrary innervation as a pathogenetic factor in the disease of the bile duct and gallbladder. Amer. J. Med. Sci., 153, 469-477, 1917.

38) Bertaccini, G. et al.: The action of caerulein on the smooth muscle of the gastrointestinal tract and the gallbladder. Brit. J. Pharmac., 34, 291-310, 1968. 